\title{
UPAYA MENINGKATKAN AKTIVITAS BELAJAR DAN HASIL BELAJAR FISIKA PADA KOMPETENSI KINEMATIKA GERAK LURUS MELALUI PEMBELAJARAN INTERPRETATIF BERBASIS ICT DI MAN KENDAL
}

\section{Purwanto}

\begin{abstract}
ABSTRAK
Masaalah rendahnya aktivitas belajar dan hasil belajar fisika di MAN Kendal akan dipecahkan dengan menggunakan pendekatan pembelajaran interpretatif, yaitu diawali dengan pembelajaran klasikal yang berbasis ICT untuk mengatasi kesulitan belajar siswa, sedangkan aktivitas siswa dibangkitkan melalui kegiatan interaksi diskusi belajar kelompok.
\end{abstract}

Penelitian ini bertujuan untuk: (1) mengetahui peningkatan aktivitas belajar siswa setelah diterapkannya metode pembelajaran interpretatif yang berbasis ICT pada materi pembelajaran kinematika gerak lurus. (2) mengetahui peningkatan hasil belajar siswa setelah diterapkannya metode pembelajaran interpretatif yang berbasis ICT pada materi pembelajaran kinematika gerak lurus mata pelajaran Fisika kelas X di MAN Kendal.

Subyek penelitian adalah siswa MAN Kendal kelas XB sejumlah 40 siswa pada Tahun pelajaran 2010/2011. Prosedur penelitian meliputi 3 tahap, yaitu: tahap persiapan (mendesain pembelajaran), tahap pelaksanaan dan tahap 
penyusunan laporan. Pelaksanaan Siklus I dan II, meliputi: perencanaan, pelaksanaan tindakan (kegiatan guru dan siswa), observasi dan reflleksi.

Pembelajaran interpretatif yang berbasis ICT dan interaksi diskusi kelompok memiliki dampak positif dalam meningkatkan hasil belajar siswa yang ditandai dengan peningkatan ketuntasan belajar siswa yaitu dari sebelum tindakan sebesar 16 siswa (40 \%) yang tuntas belajar (yang memperoleh nilai di atas KKM $=65,0)$ pada Siklus I menjadi 26 siswa (65\%), dan pada Siklus II meningkat menjadi 32 siswa atau $80 \%$.

Berdasarkan hasil analisis aktivitas siswa dalam kelompoknya serta hasil belajar siswa dalam pemberian tindakan dengan menggunakan pembelajaran interpretatif berbasis ICT diperoleh peningkatan baik aktivitas siswa dalam kelompok maupun hasil belajar siswa, sehingga dapat disimpulkan bahwa pembelajaran interpretatif berbasis ICT mampu meningkatkan aktivitas maupun hasil belajar siswa pada kompetensi kinematika gerak lurus mata pelajaran Fisika kelas X di MAN Kendal.

Kata kunci: Pembelajaran Interpretatif, ICT; Aktivitas Belajar; Hasil Belajar.

\section{A. PENDAHULUAN}

\section{Latar Belakang Masalah}

Pembelajaran fisika di MAN Kendal khususnya di kelas $X$ agaknya aktivitas dan hasil belajar masih rendah, hal ini ditandai minat dan kemampuan dalam pencapaian KKM (Kriteria Ketuntasan Minimal) yang dibawah standar, semangat belajar yang kendor, kemampuan dalam proses menghitung juga rendah, kemampuan menganalisa soal sangat terbatas, secara umum aktivitas dan hasil belajar masih rendah.

Pembelajaran klasikal yang berlangsung saat ini akan men- 
jadi lebih bervariatif jika guru mampu memadukan keberadaan metode dan peralatan bantu media lain yang tersedia di madrasah. Proses pembelajaran fisika yang dilaksanakan secara interpretatif dan berbasis ICT (Information and Communication Technology) diharapkan memberi perubahan yang cukup berarti dalam proses pencapaian hasil.

Atas dasar pencapaian tujuan hasil belajar fisika siswa yang masih rendah penulis tertarik untuk melakukan Penelitian Tindakan Kelas (PTK) dengan perlakukan proses interpretatif yang berbasis ICT dalam pembelajaran fisika yang berlangsung terhadap siswa.

\section{Identifikasi Masalah}

Menurut Arikunto (2006:21) dikatakan bahwa hasil belajar siswa diduga terkait dengan banyak faktor, antara lain faktor internal (faktor biologis dan psikologis) dan faktor eskternal ( faktor manusia (human) dan faktor non manusia. Faktor internal siswa diantaranya seperti motivasi, percaya diri, ketekunan, kedisiplinan, dan lain-lain, sedang faktor eskternal seperti faktor dari guru, keluarga, masyarakat dan faktor non manusia seperti kurikulum, sarana/media pengajaran, metode pembelajaran, bahan meteri pelajaran, lingkungan/situasi dan lain-lain. Berpijak dari temuan di atas diduga bahwa peningkatan aktivitas dan hasil belajar siswa banyak dipengaruhi oleh pemanfaatan media pembelajaran dan metode pembelajaran yang digunakan oleh guru.

\section{Pembatasan Masalah}

Peneliti membatasi masalah yang meliputi:

1. Hanya pada faktor sarana/media pembelajaran yang berbasis ICT diduga cukup besar pengaruhnya terhadap peningkatan aktivitas belajar dan hasil belajar siswa.

2. Penelitian ini dilakukan di Kelas $X B$ semester gasal tahun pelajaran 2010/2011.

3. Materi yang disampaikan dalam penelitian ini adalah kinematika gerak lurus (GLB dan GLBB) 


\section{Purwanto}

\section{Rumusan Masalah}

Apakah pembelajaran interpretatif yang berbasis ICT dapat meningkatkan aktivitas belajar siswa dan hasil belajar siswa pada materi pembelajaran kinematika gerak lurus?

\section{Cara Pemecahan Masalah}

Masaalah rendahnya aktivitas belajar dan hasil belajar fisika di kelas XB di MAN Kendal akan dipecahkan dengan menggunakan pendekatan pembelajaran interpretatif, yaitu diawali dengan pembelajaran klasikal yang berbasis ICT, melalui pemilihan media ICT sebagai alat bantu pembelajaran karena media ICT ini diharapkan mampu menciptakan pembelajaran menjadi inspiratif, inovatif, menyenangkan, menantang, dan memotivasi sehingga kesulitan belajar siswa dapat teratasi. Kemudian aktivitas siswa dibangkitkan melalui kegiatan interaksi diskusi belajar kelompok.

\section{Tujuan Penelitian}

Ingin mengetahui peningkatan aktivitas belajar siswa dan hasil belajar siswa setelah diterapkannya metode pembelajaran interpretatif yang berbasis ICT pada materi pembelajaran kinematika gerak lurus.

\section{Manfaat Penelitian}

1. Manfaat Teoritis : Hasil penelitian ini diharapkan dapat menyumbangkan suatu model pembelajaran yang berbasis ICT yang mampu untuk meningkatkan mutu pendidikan madrasah, dan sebagai dasar untuk penelitian selanjutnya.

2. Manfaat Secara Praktis:

a. Bagi siswa: Adanya variasi belajar dan suasana belajar menjadi lebih aktif.

b. Bagi Guru: Memberikan alternatif variasi model pembelajaran Fisika

c. Bagi Sekolah/Madrasah: Sebagai sumbangan pemikiran penulis. 


\section{B. KAJIAN TEORI DAN PENGAJUAN HIPOTESIS}

\section{Landasan Teori}

\section{Hakekat dan Pembelajaran Fisika}

a. Hakekat Fisika

Bridgman dalam Lestari (2002:7), Depag (2002:2).

Hakikat fisika merupakan bagian dari fisika, dimana konsep-konsepnya diperoleh melalui suatu proses dengan menggunakan metode ilmiah dan diawali dengan sikap ilmiah kemudian diperoleh hasil (produk).

b. Pembelajaran Fisika

Depag (2002:4), Depdiknas (2006:19), Sumiati (2008:113).

Pembelajaran Fisika seharusnya sesuai dengan ciri-ciri karakteristik Fisika. Oleh sebab itu, kegiatan siswa dalam mempelajari Fisika sebaiknya sama dengan kegiatan Fisikawan dalam mengembangkan Fisika. Siswa harus melakukan pengamatan, pengukuran, analisis data dan menarik kesimpulan-kesimpulan yang berwujud konsep, teori, hukum dan azas-azas Fisika dalam kegiatan belajarnya.

\section{Aktivitas Belajar dan Hasil Belajar}

a. Konsep Aktivitas Belajar

Sardiman (2007:93), Montessori dalam Hamalik (2006:171), Whipple dalam Hamalik (2006:173-174).

Aktivitas belajar yang dimaksud adalah seluruh aktivitas siswa dalam proses belajar, dengan belajar mereka memperoleh pengetahuan, pemahaman, dan aspek-aspek tingkah laku lainnya. Serta mengembangkan keterampilan yang bermakna untuk hidup dimasyarakat, sehingga kegiatan belajar siswa menjadi dasar untuk mencapai tujuan dan hasil belajar yang lebih memadai.

b. Hasil Belajar Siswa

Slameto (2007:89), Usman (2006:21), Ngalim Purwanto (2007:107), Arikunto (2006:21). 
Hasil belajar yang dimaksud adalah kemampuan dalam memahami, memformulasikan menghitung dan menganalisa soal dalam mencapai suatu tujuan yang ada pada indikator RPP (Rencana Pelaksanaan Pembelajaran) yang telah ditentukan dapat menerapkan dalam kehidupan sehari-hari. Karena suatu proses dikatakan berhasil apabila dilihat output dalam hal ini hasil belajar siswa, baik secara individual maupun kelompok. Hasil belajar yang diharapkan sekolah yakni tercapai $75 \%$ siswa telah mencapai kriteria ketuntasan minimal (KKM).

\section{Pembelajaran Interpretatif berbasis ICT}

a. Konsep Media ICT

Asnawir (2006:vii), Hamalik (2006:235), Rudi Susilana (2008:124), Usman (2006:32), Dimyati (2002:36), Depag (2002:6).

Strategi peningkatan kualitas pembelajaran dapat dilakukan dengan berbagai strategi antara lain melalui pembelajaran berbasis pemanfaatan Information and Communication Technology atau ICT dengan berstandar pada penguasaan kompetensi (competency based learning). Pembelajaran Yang berbasis ICT adalah pembelajaran yang memakai media Teknologi dan Komunikasi atau ICT. Penggunaan media berbasis ICT dalam pembelajaran sangat memudahkan bagi guru dalam menyajikan materi pelajaran, seperti simulasi untuk melakukan percobaan pada materi sains dan teknologi, dengan Program Microsoft Power Point, dapat menbuat gambar yang bergerak (animasi), materi dengan latar belakang gambar atau foto. Desain gambar lebih menarik, akan merangsang siswa lebih banyak beraktivitas. Disamping itu siswa juga dapat mencari bahan-bahan atau materi lain dari internet.

b. Pendekatan Pembelajaran Interpretatif

Sumiati (2008:12), Djamarah (2005:6).

Pendekatan pembelajaran interpretatif berbasis ICT yang dimaksud adalah pendekatan pembelajaran dengan menggunakan metode ceramah dan metode belajar kelompok (diskusi kelompok) yang dilaksanakan secara klasikal dengan memanfaatkan media pembelajaran interaktif dengan pembelajaran 
yang dikemas dalam program presentasi powerpoint dan $C D$ pembelajaran interaktif.

\section{c. Interaksi Diskusi Kelompok}

Slavin dalam Supriyono (2003:54), Sukidin (2002:15).

Interaksi diskusi kelompok merupakan pendekatan yang sederhana dalam pembelajaran, dalam interaksi diskusi kelompok terdiri atas empat siswa yang mewakili keseimbangan kelas dalam kemampuan akademik. Ada empat tahap dalam interaksi diskusi kelompok yaitu; pengajaran, studi kelompok, ulangan atau tes, dan penghargaan.

\section{Penelitian Yang Relevan}

1. Suparman (2007): bahwa pembelajaran berbasis ICT mampu meningkatkan aktivitas dan hasil belajar fisika materi listrik statis di SMA Negeri 4 Kendari.

2. Agam Supriyanta (2007): bahwa pembelajaran interpretatif dengan pembelajaran yang berbasis internet mampu meningkatkan hasil belajar fisika di SMAN 2 Cianjur.

3. Homsyer yang dikutip Rudi Susilana (2008:1255), dengan memberikan dua perlakuan yang berbeda, kelas yang belajar dengan Computer Assisted Instruction (CAI) yang berbasis ICT dibandingkan dengan kelas tatap muka, hasilnya menunjukkan bahwa terjadi penghematan waktu yang signifikan. 


\section{KERANGKA BERFIKIR}

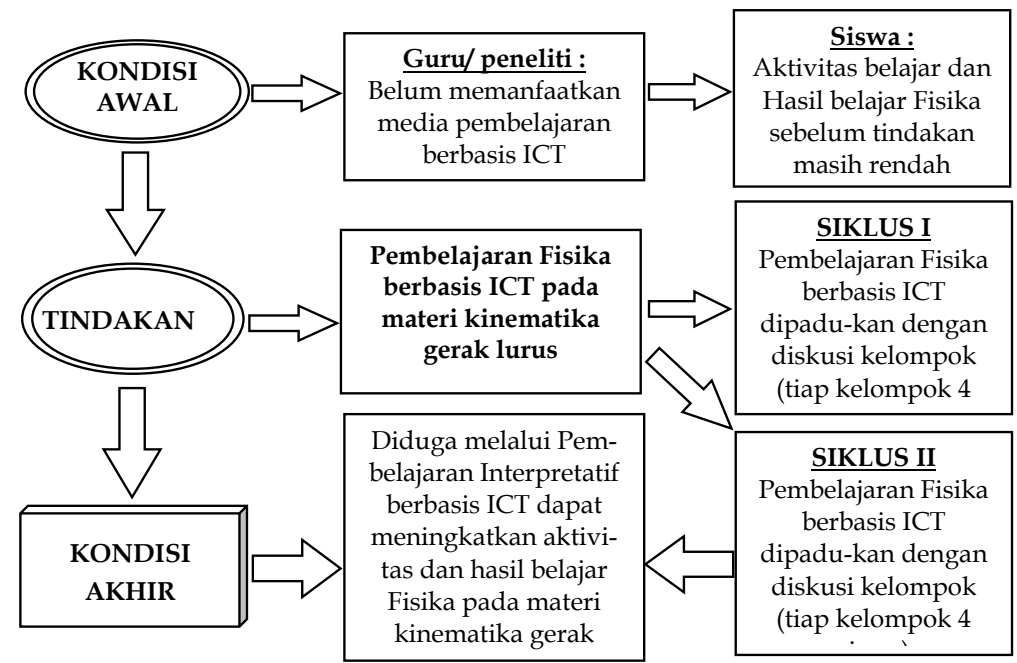

\section{Hipotesis Tindakan}

1. Pembelajaran interpretatif yang berbasis ICT dapat meningkatkan aktivitas belajar pada materi pembelajaran kinematika gerak lurus.

2. Pembelajaran interpretatif yang berbasis ICT dapat meningkatkan hasil belajar pada materi pembelajaran kinematika gerak lurus.

\section{METODE PENELITIAN}

\section{Setting Penelitian}

Kegiatan penelitian ini dilaksanakan pada tahun pelajaran 2010/2011 semester gasal, tepatnya dimulai pada bulan Agustus sampai dengan bulan Oktober tahun 2010, sesuai kalender pendidikan (Kaldik) dan program semester (Promes) yang bertepatan dengan penyampaian materi pembelajaran kompetensi kinematika gerak lurus mata pelajaran Fisika Kelas X (sepuluh) di MAN Kendal.

\section{Subyek Penelitian}

Populasi penelitian sejumlah 10 kelas dengan jumlah siswa 
400 siswa, sedangkan subyek penelitian diambil dari kelas X-B yang hasil belajar siswa pada pembelajaran kompetensi sebelumnya masih rendah dibanding kelas yang lain. Jumlah siswa Kelas X-B ada 40 siswa, terdiri dari 12 siswa putra dan 28 siswa putri.

\section{Faktor Yang Diselidiki}

Faktor siswa; faktor guru; faktor sumber dan media pembelajaran.

\section{Teknik Dan Alat Pengumpul Data}

\section{Sumber Data}

Sumber data di dapat dari siswa kelas X-B dengan segala macam bentuk kegiatan yang dilaksanakan di kelas. Selain itu sumber data diperoleh dari teman guru fisika sebagai pengamat (kolaborator) dalam penelitian.

\section{Jenis Data}

Jenis data yang diperoleh adalah data kualitatif dan kuantitatif yang terdiri dari :

a. Tes hasil belajar berupa tes hasil belajar produk dan tes unjuk kerja

b. Lembar obsevasi

c. Jurnal siswa

\section{Cara Pengambilan data}

a. Aktivitas siswa selama mengikuti proses pembelajaran diperoleh dengan cara mengamati kegiatan siswa yang ada kaitannya dengan proses pembelajaran di kelas dan mencatatnya pada lembar observasi.

b. Konsepsi siswa tentang kinematika gerak lurus:

1). Konsepsi awal siswa sebelum mengikuti proses pembelajaran diperoleh melalui lembar jawaban pertanyaan yakni dengan cara meminta siswa menjawab pertanyaan secara tertulis sebagai kegiatan awal dari tiap-tiap proses pembelajaran yang akan dilaksanakan. 
2). Konsepsi siswa setelah mengikuti pembelajaran diperoleh melalui ulangan atau tes akhir pada setiap siklus pembelajaran.

Untuk menilai ulangan atau tes formatif, diperoleh rata-rata tes formatif dengan rumus:

$$
\begin{aligned}
& \bar{X}=\frac{\sum X}{\sum N} \\
& \text { Dengan: } \bar{X} \quad=\text { Nilai rata-rata } \\
& \Sigma X \quad=\text { Jumlah semua nilai siswa } \\
& \Sigma \mathrm{N} \quad=\text { Jumlah siswa }
\end{aligned}
$$

Sedangkan untuk ketuntasan belajar, ada dua kategori ketuntasan belajar yaitu secara perorangan dan secara klasikal. Untuk menghitung persentase ketuntasan belajar secara klasikal digunakan rumus sebagai berikut:

$$
P=\frac{\sum \text { Siswa yang tuntas belajar }}{\sum \text { Siswa }} \times 100 \%
$$

Untuk mengetahui hasil belajar siswa secara klasikal dengan menggunakan alat atau instrumen (tes/ulangan) tersebut yang hasilnya dinyatakan dengan kriteria: sangat baik, baik, cukup baik, dan kurang baik.

Sedangkan untuk menghitung nilai peningkatan individu dihitung berdasarkan nilai yang diperoleh siswa sebelum tindakan atau disebut nilai dasar. Nilai peningkatan kelompok diperoleh dari jumlah nilai peningkatan individu dari masing-masing anggota kelompok dibagi dengan jumlah anggota kelompok yang hadir. Empat tingkat penghargaan diberikan berdasar nilai rata-rata kelompok, yaitu: terbaik, baik, cukup baikdan kurang baik. 


\section{Validasi Data}

Aktivitas belajar siswa divalidasi dengan lembar observasi kerjasama antar siswa yang memuat kerjasama dalam diskusi kelompok, bertanya teman, bertanya guru, presentasi, serta menjawab pertanyaan baik lesan atau tertulis.

Hasil belajar pada setiap siklus divalidasi dengan instrumen yang berupa: Soal tes, Lembar Jawab, Kunci Jawaban, Soal Tes, Hasil atau Nilai Tes, dan Rencana Pelaksanaan Pembelajaran (RPP) pada setiap siklus.

\section{Analisis Data}

Analisis yang digunakan adalah analisis deskriptif kualitatif, yaitu untuk analisis hasil belajar dengan membandingkan nilai tes, meliputi nilai tes sebelum tindakan, Siklus I dan Siklus II dengan indikator kerja. Analisis aktivitas belajar siswa dengan memaparkan hasil observasi.

\section{Prosedur Penelitian}

\section{Rencana Tindakan}

Pelaksanaan tindakan pada setiap siklus dilakukan dengan melalui Prosedur: Perencanaan, Pelaksanaan Tindakan, Observasi/Evaluasi, dan refleksi, seperti dijelaskan sebagai berikut: Persiapan, Penyajian Materi, Interaksi kelompok, Penyajian Hasil Belajar, dan Penskoran Kemajuan Individu.

\section{Rencana Pengembangan}

Rencana pengembangan ini dilaksanakan melalui prosedur PTK yaitu: Perencanaan, Pelaksanaan tindakan, Observasi, Evaluasi, dan Refleksi.

Secara rinci siklus pengembangan ini dijabarkan sebagai berikut:

\section{a. Siklus I}

\section{1). Perencanaan}

Membuat Rencana Pelaksanaan Pembelajaran (RPP), membuat test, mempersiapkan CD Pembelajaran fisika yang berhubungan dengan kompetensi kinematika gerak lurus dan 
menyiapkan materi pembelajaran untuk ditampilkan dengan Program PowerPoint.

\section{2). Pelaksanaan tindakan}

Pada tahap ini semua media sudah siap di operasikan, guru menayangkan materi itu yang didalamnya sudah ada tujuan yang akan dicapai pada kompetensi dasar di materi itu. Kemudian guru menyampaikan pertama apersepsi, kegiatan inti dan kegiatan akhir.

\section{3). Refleksi}

Refleksi yaitu dengan memperhatikan kejadian-kejadian selama proses pembelajaran dari lembar observasi dengan hasil tes yang dicapai siswa dan jurnal harian. Dengan memperhatikan kelemahan dan kekurangan serta hambatan-hambatan dalam memecahkan masalah pada siklus I, sehingga menjadi bahan pertimbangan perbaikan pada perencanaan siklus II.

Indikator keberhasilan Siklus 1, apabila $65 \%$ siswa telah mencapai ketuntasan belajar produk dan proses secara klasikal dengan skor/nilai diatas KKM (dengan nilai $=65,0$ ).

\section{b. Siklus II}

\section{1). Perencanaan}

a). Menetapkan/merumuskan keunggulan dan kelemahan yang dicapai pada kegiatan Siklus 1,

b). Meninjau kembali Rencana Pelaksanaan Pembelajaran (RPP) pada materi pokok kinematika gerak lurus.

c). Mengevalusi kembali alat bantu media ICT, Lembar kerja Siswa ( LKS), lembar observesi untuk kegiatan siswa dan guru, alat evaluasi penilaian hasil belajar yang telah disiapkan.

\section{2). Pelaksanaan Tindakan}

Kegiatan yang dilaksanakan dalam tahap ini adalah melaksanakan skenario yang sesuai dengan RPP kinematika gerak lurus. Adapun gambaran pelaksanaan tindakan pada siklus II: 
Kegiatan pendahuluan, kegiatan inti, dan penutup.

\section{3). Obsevasi / Evaluasi}

Pelaksanaan observasi dimaksudkan untuk mengetahui keaktifan siswa dan kemampuan guru membimbing dan memfasilitasi dalam pembelajaran melalui alat bantu media ICT. Evaluasi dilaksanakan untuk megetahui sejauh mana siswa menguasai konsep setelah diberikan tindakan.

\section{4). Refleksi}

Dari hasil tes dianalisa dengan membandingkan nilai tes pada siklus II dengan nilai tes pada siklus I. Refleksi yaitu dengan memperhatikan kejadian-kejadian selama proses pembelajaran dari lembar observasi dengan hasil tes yang dicapai siswa, sebagai upaya evaluasi yang dilakukan guru dan kolaborator (teman guru) dalam penelitian tindakan kelas (PTK). Kolaborator adalah teman guru yang juga mengajar fisika dikelas paralel (kelas X) di madrasah tempat dilakukannya penelitian tindakan kelas (PTK).

Refleksi dilakukan dengan cara berdiskusi terhadap berbagai masalah yang muncul di kelas penelitian yang diperoleh dari analisis data sebagai bentuk dari pengaruh tindakan yang telah dirancang. Hasil refleksi digunakan untuk menetapkan langkah-langkah lebih lanjut. Indikator keberhasilan Siklus II, apabila $75 \%$ siswa telah mencapai ketuntasan belajar produk dan proses secara klasikal dengan skor/nilai KKM diatas 65,0. 
Purwanto

\section{JADWAL KEGIATAN KARYA TULIS ILMIAH}

Tabel 4. Waktu dan Jadwal Kegiatan Penelitian Tindakan Kelas (PTK)

\begin{tabular}{|c|c|c|c|c|c|c|c|c|c|c|c|c|c|c|}
\hline \multirow{3}{*}{ JENIS KEGIATAN } & \multicolumn{14}{|c|}{ WAKTU PELAKSANAAN } \\
\hline & \multicolumn{5}{|c|}{ Agustus } & \multicolumn{4}{|c|}{ September } & \multicolumn{5}{|c|}{ Oktober } \\
\hline & 1 & 2 & 3 & 4 & 5 & 1 & 2 & 3 & 4 & 1 & 2 & 3 & 4 & 5 \\
\hline $\begin{array}{l}\text { Penentuan Masalah } \\
\text { Penelitian }\end{array}$ & $\mathrm{x}$ & & & & & & & & & & & & & \\
\hline $\begin{array}{l}\text { Pembuatan Pro- } \\
\text { posal Penelitian \& } \\
\text { Pengajuan }\end{array}$ & $\mathrm{x}$ & & & & & & & & & & & & & \\
\hline $\begin{array}{l}\text { Revisi Proposal dan } \\
\text { penentuan obyek } \\
\text { penelitian }\end{array}$ & $\mathrm{x}$ & & & & & & & & & & & & & \\
\hline $\begin{array}{l}\text { Pembuatan Admin- } \\
\text { istrasi }\end{array}$ & & $\mathrm{x}$ & & & & & & & & & & & & \\
\hline $\begin{array}{l}\text { Persiapan Media } \\
\text { ICT }\end{array}$ & & & $\mathrm{x}$ & & & & & & & & & & & \\
\hline Pelaksanaan Siklus I & & & & $\mathrm{x}$ & & & & & & & & & & \\
\hline $\begin{array}{l}\text { Evaluasi (Tes) Hasil } \\
\text { Siklus1 }\end{array}$ & & & & & $\mathrm{x}$ & & & & & & & & & \\
\hline $\begin{array}{l}\text { Perbaikan Temuan } \\
\text { Kekurangan pada } \\
\text { Siklus I }\end{array}$ & & & & & & $\mathrm{x}$ & & & & & & & & \\
\hline $\begin{array}{l}\text { Pelaksanaan Siklus } \\
\text { II }\end{array}$ & & & & & & & $\mathrm{x}$ & $\mathrm{x}$ & & & & & & \\
\hline $\begin{array}{l}\text { Evaluasi (tes) Hasil } \\
\text { Siklus II }\end{array}$ & & & & & & & & & $\mathrm{x}$ & & & & & \\
\hline $\begin{array}{l}\text { Tabulasi Analisis } \\
\text { Data }\end{array}$ & & & & & & & & & & $\mathrm{x}$ & & & & \\
\hline Penyusunan Draf & & & & & & & & & & & $\mathrm{x}$ & & & \\
\hline $\begin{array}{l}\text { Seminar Hasil Pene- } \\
\text { litian }\end{array}$ & & & & & & & & & & & & $\mathrm{x}$ & & \\
\hline $\begin{array}{l}\text { Pembuatan Laporan } \\
\text { - PTK }\end{array}$ & & & & & & & & & & & & & $\mathrm{x}$ & \\
\hline $\begin{array}{l}\text { Pelaporan Hasil } \\
\text { PTK }\end{array}$ & & & & & & & & & & & & & $\mathrm{x}$ & $\mathrm{x}$ \\
\hline
\end{tabular}




\section{HASIL PENELITIAN DAN PEMBAHASAN}

\section{Diskripsi Kondisi Awal}

Hasil ulangan harian (formatif) Kelas X-B pada tes kompetensi dasar sebelumnya (sebelum tindakan) diperoleh hasil yang masih rendah, yaitu hanya $40 \%$ atau 16 siswa dari 40 siswa yang memperoleh nilai secara klasikal di atas Kriteria Ketuntasan Minimal (KKM) dengan batas nilai 65,0. Hal ini disebabkan karena aktivitas belajar dan hasil belajar siswa yang masih rendah, cara pembelajaran yang masih terfokus pada guru, dan rasa canggung untuk bertanya guru, serta belum terbiasa dengan belajar interaksi dalam diskusi kelompok. Selain itu juga karena siswa merasa kesulitan dengan menghafal banyak rumus. Pada hal belajar fisika tidak semestinya menghafal, tetapi lebih ditekankan pada pemikiran dan penalaran konsep.

\section{Diskripsi Siklus I}

\section{Perencanaan Tindakan}

Pada tahap ini guru merencanakan pembelajaran dengan menyusun Rencana Pelaksanaan Pembelajaran (RPP-1) pada materi pokok kinematika gerak lurus (GLB dan GLBB) dengan mempertimbangkan kondisi awal, menyiapkan bahan ajar, sumber dan bahan presentasi, LKS (Lembar kerja Siswa), menyusun soal tes formatif I, mempersiapkan CD pembelajaran fisika, mendesain presentasi pembelajaran dengan program Powerpoint yang berhubungan dengan kompetensi kinematika gerak lurus (GLB dan GLBB), selain itu juga dipersiapkan lembar observasi kegiatan aktivitas guru dan siswa dalam proses belajarmengajar.

\section{Pelaksanaan Tindakan}

Pada tahap pelaksanaan ini guru menyampaikan pertama apersepsi, kegiatan inti dan kegiatan akhir. Pelaksanaan kegiatan belajar mengajar untuk siklus I dilaksanakan pada tanggal 30 September dan 1 Oktober 2010 di kelas XB dengan jumlah siswa sebanyak 40 siswa dan membagi siswa dalam kelompok 
Purwanto

belajar.

Dalam hal ini peneliti bertindak sebagai guru fisika. Adapun proses belajar mengajar mengacu pada rencana pelajaran yang telah dipersiapkan. Pengamatan (observasi) dilaksanakan bersamaan dengan pelaksaaan proses belajar mengajar.

\section{Hasil Pengamatan}

\section{a. Hasil Belajar Siswa}

1) Nilai Individu Siswa

Tabel 4.3. Rekapitulasi Hasil Tes Formatif Siswa pada Siklus I

\begin{tabular}{|c|l|c|c|}
\hline No. & \multicolumn{1}{|c|}{ Uraian } & $\begin{array}{c}\text { Hasil } \\
\text { Siklus I }\end{array}$ & Ket. \\
\hline 1. & Nilai terendah tes formatif & 60,0 & 14 siswa \\
2. & Nilai tertinggi tes formatif & 92,0 & belum \\
3. & Nilai rata-rata tes formatif & 70,8 & tuntas \\
4. & Jumlah siswa yang tuntas belajar & 26 siswa & belajar \\
5. & Prosentase ketuntasan belajar & $65 \%$ & \\
\hline
\end{tabular}

Tabel 5. Distribusi dan Kategori Nilai Siklus I

\begin{tabular}{|c|c|c|c|c|c|}
\hline No. & $\begin{array}{c}\text { Interval } \\
\text { Nilai }\end{array}$ & $\begin{array}{c}\text { Jumlah } \\
\text { Siswa }\end{array}$ & $\begin{array}{l}\text { Prosen- } \\
\text { tase }(\%)\end{array}$ & Kategori & Ket \\
\hline 1. & $88-100$ & 3 & 7,5 & Sangat Baik & $>\mathrm{KKM}$ \\
\hline 2. & $77-87$ & 8 & 20,0 & Baik & $>$ KKM \\
\hline 3. & $65-76$ & 15 & 37,5 & Cukup Baik & $>\mathrm{KKM}$ \\
\hline 4. & $0-64$ & 14 & 35,0 & Kurang Baik & $\begin{array}{c}<\mathrm{KKM} \\
(65,0)\end{array}$ \\
\hline \multicolumn{2}{|c|}{ Jumlah } & 40 & $100 \%$ & --- & -- \\
\hline
\end{tabular}

Dengan demikian dari sudut ketuntasan belajar (yang mendapat nilai di atas KKM secara klasikal atau yang memperoleh nilai hasil belajar lebih dari 65,0) pada Siklus I sebesar 26 siswa atau $65 \%$.

2) Nilai Kelompok

Tabel 6. Penghargaan Kelompok Pada Siklus I

102 Jurnal PHENOMENON, Volume 2 Nomor 1, November 2011 
Upaya Meningkatkan Aktivitas Belajar .....

\begin{tabular}{|c|c|c|c|c|}
\hline No & Kategori & Kelompok & $\begin{array}{c}\text { Jumlah } \\
\text { Kelompok }\end{array}$ & $\begin{array}{c}\text { Prosentase } \\
(\%)\end{array}$ \\
\hline 1 & Terbaik & 7 & 1 & 10 \\
2 & Baik & $2,3,5,6,10$ & 5 & 50 \\
3 & Cukup Baik & $1,4,8$ & 3 & 30 \\
4 & Kurang baik & 9 & 1 & 10 \\
\hline \multicolumn{2}{|c|}{ Jumlah } & 10 & $100 \%$ \\
\hline
\end{tabular}

Dari tabel di atas dapat dilihat bahwa kelompok 7 mendapat penghargaan sebagai kelompok terbaik, sedang kelompok 2, 3, 5, 6 dan 10 mendapat penghargaan kelompok baik.

\section{b. Observasi}

Jika dikaitkan dengan hasil observasi guru oleh kolaborator guru fisika terhadap aktivitas siswa dalam kelompoknya selama proses belajar mengajar sudah cukup baik tetapi belum sesuai dengan apa yang diharapkan. Hal ini disebabkan antara lain, siswa belum terlalu paham dengan penerapan pendekatan media ICT dalam proses pembelajaran, sehingga mengakibatkan aktivitas siswa tidak optimal, siswa lebih tertarik dengan penampilan pembelajaran yang berbasis ICT ini sehingga kurang konsentrasi dalam memahami materi/konten dari pelajaran itu sendiri.

Namun demikian dari hasil observasi dapat diamati terjadi peningkatan aktivitas dan interaksi antar siswa dalam diskusi kelompok, sebagain besar siswa mampu memberikan kontribusi atau pendapat dalam menyelesaikan tugas-tugas kelompoknya, meskipun ada beberapa siswa yang belum mampu menyelesaikan soal yang diberikan kepada kelompoknya.

\section{Refleksi}

Hasil belajar siswa juga mengalami peningkatan dimana sebelum tindakan, siswa yang tuntas belajar hanya $40 \%$ atau 16 siswa, setelah dilakukan tindakan pada Siklus I meningkat menjadi $65 \%$ atau 26 siswa telah tuntas belajar.

Kekurangan-kekurangan pada pelaksanaan kegiatan belajar-mengajar pada siklus I perlu adanya revisi untuk dilaksanakan pada siklus II antara lain: 
1. Guru dalam memotivasi siswa hendaknya dapat membuat siswa lebih termotivasi selama proses belajar mengajar berlangsung.

2. Guru harus lebih dekat dengan siswa sehingga tidak ada perasaan takut dalam diri siswa baik untuk mengemukakan pendapat atau bertanya.

3. Guru harus lebih sabar dalam membimbing siswa merumuskan kesimpulan atau menemukan konsep.

4. Guru harus mendistribusikan waktu secara baik sehingga kegiatan pembelajaran dapat berjalan sesuai dengan yang diharapkan.

5. Guru sebaiknya menambah lebih banyak contoh soal dan memberi soal-soal latihan pada siswa untuk dikerjakan pada setiap kegiatan belajar mengajar.

\section{Diskripsi Siklus II}

Kesalahan tindakan yang terjadi pada Siklus I diperbaiki pada Siklus II, yang juga terdiri dari kegiatan perencanaan, tindakan, observasi, dan refleksi, dengan merancang berdasarkan kesalahan, kelemahan, dan kekurangan yang sudah terjadi pada Siklus I.

\section{Perencanaan Tindakan}

Dengan menetapkan/merumuskan keunggulan dan kelemahan yang dicapai pada kegiatan Siklus 1, pada tahap ini peneliti mempersiapkan perangkat pembelajaran yang terdiri dari Rencana Pelaksanaan Pembelajaran (RPP-2) dengan materi pokok kinematika gerak lurus (penerapan GLBB, gerak jatuh bebas dan gerak vertikal ke atas), menyiapkan bahan ajar, sumber dan bahan presentasi, LKS (Lembar kerja Siswa), mengevalusi kembali media ICT dan alat-alat pengajaran pendukung, menyusun soal tes formatif II, mempersiapkan CD pembelajaran fisika, mendesain presentasi pembelajaran dengan program Powerpoint yang berhubungan dengan kompetensi kinematika gerak lurus, selain itu juga dipersiapkan lembar observasi kegiatan aktivitas guru dan siswa dalam proses belajar-mengajar.

104 Jurnal PHENOMENON, Volume 2 Nomor 1, November 2011 


\section{Pelaksanaan Tindakan}

Pada tahap pelaksanaan ini, meliputi: Kegiatan Pendahuluan, Kegiatan Inti: guru menyampaikan pokok-pokok materi yang berhubungan dengan materi kinematika gerak lurus (pengembangan GLBB+/-, gerak vertikal keatas dan gerak jatuh bebas), Kegiatan Penutup: tes formatif II.

Pelaksanaan kegiatan belajar mengajar untuk siklus II dilaksanakan pada tanggal 7 dan 8 Oktober 2010 di kelas XB dengan jumlah siswa sebanyak 40 siswa. Dalam hal ini peneliti bertindak sebagai guru. Adapun proses belajar mengajar mengacu pada rencana pelajaran dengan memperhatikan revisi pada siklus I, sehingga kesalahan atau kekurangan pada siklus I tidak terulang lagi pada siklus II. Pengamatan (observasi) dilaksanakan bersamaan dengan pelaksanaan proses belajar mengajar.

\section{Hasil Pengamatan}

\section{a. Hasil belajar Siswa}

1) Nilai Individu Siswa

Tabel 4.3. Rekapitulasi Hasil Tes Formatif Siswa pada Siklus II

\begin{tabular}{|c|l|c|c|}
\hline No. & \multicolumn{1}{|c|}{ Uraian } & $\begin{array}{c}\text { Hasil Sik- } \\
\text { lus II }\end{array}$ & \multicolumn{1}{|c|}{ Ket. } \\
\hline 1. & Nilai terendah tes formatif & 60,0 & \\
2. & Nilai tertinggi tes formatif & 95,0 & 8 siswa \\
3. & Nilai rata-rata tes formatif & 74,0 & belum \\
4. & Jumlah siswa yang tuntas belajar & 32 siswa & tuntas \\
5. & Prosentase ketuntasan belajar & $80 \%$ & \\
\hline
\end{tabular}

Tabel 7. Distribusi dan Kategori Nilai Siklus II

\begin{tabular}{|c|c|c|c|c|c|}
\hline No. & $\begin{array}{c}\text { Interval } \\
\text { Nilai }\end{array}$ & $\begin{array}{c}\text { Jumlah } \\
\text { Siswa }\end{array}$ & $\begin{array}{c}\text { Prosen- } \\
\text { tase (\%) }\end{array}$ & Kategori & Keterangan \\
\hline 1. & $88-100$ & 6 & 15,0 & Sangat Baik & $>$ KKM \\
2. & $77-87$ & 10 & 25,0 & Baik & $>$ KKM \\
3. & $65-76$ & 16 & 40,0 & Cukup Baik & $>$ KKM \\
4. & $0-64$ & 8 & 20,0 & Kurang Baik & $<$ KKM $(65,0)$ \\
\hline \multicolumn{7}{|r|}{ Jumlah } & 40 & $100 \%$ & -- & \\
\hline
\end{tabular}


Dengan demikian dari sudut ketuntasan belajar (yang mendapat nilai diatas KKM atau lebih dari 65,0) pada Siklus II sejumlah 32 siswa atau $80 \%$, sedangkan 8 siswa atau $20 \%$ dinyatakan masih belum tuntas belajar.

2) Nilai Kelompok

Tabel 8. Penghargaan Kelompok Pada Siklus II

\begin{tabular}{|c|l|c|c|c|}
\hline No. & \multicolumn{1}{|c|}{ Kategori } & Kelompok & $\begin{array}{c}\text { Jumlah } \\
\text { Kelompok }\end{array}$ & $\begin{array}{c}\text { Prosentase } \\
(\%)\end{array}$ \\
\hline 1 & Terbaik & $2,3,6,7$ & 4 & 40 \\
2 & Baik & $1,4,5,8,10$ & 5 & 50 \\
3 & Cukup Baik & 9 & 1 & 10 \\
4 & Kurang baik & 0 & 0 & 0 \\
\hline \multicolumn{2}{|c|}{ Jumlah } & 10 & $100 \%$ \\
\hline
\end{tabular}

Dari tabel di atas dapat dilihat bahwa kelompok 2, 3, 6, dan 7 mendapat penghargaan sebagai kelompok terbaik. sedang kelompok 1, 4, 5, 8, dan 10 mendapat penghargaan kelompok baik. Pada Siklus II ini tidak ada kelompok yang kinerjanya mendapat kategori kurang baik.

\section{b. Observasi}

Berdasarkan hasil observasi pada Siklus II ini baik aktivitas guru maupun aktivitas siswa telah menunjukkan peningkatan yang positif.

\section{Hal ini ditandai dengan:}

1. Selama proses pembelajaran berlangsung siswa selalu berada dalam kelompoknya.masing-masing serta bersedia menerima tugas apapun yang diberikan oleh teman kelompoknya.

2. Siswa sudah mampu mengerjakan kegiatan sekaligus menyelesaikan soal yang ditugaskan kepada kelompoknya.

3. Apabila terdapat hal-hal yang kurang dimengerti, tanpa ragu-ragu siswa segera bertanya baik, kepada anggota kelompoknya maupun kepada guru sehingga mereka mampu 
mengemukakan pendapatnya dan menjawab pertanyaan baik kepada guru atau anggota kelompoknya.

Selain itu pula siswa sudah menyadari dan memahami sasaran yang harus dicapai dalam pembelajaran dengan menggunakan media pembelajaran ICT sehinga sebagian besar siswa aktif dalam proses belajar mengajar.

\section{Refleksi}

Pada tahap ini akan dikaji apa yang telah terlaksana dengan baik maupun yang masih kurang baik dalam proses belajar mengajar dengan penerapan metode pembelajaran interpretatif yang berbasis ICT dan interaksi diskusi kelompok. Dari datadata yang telah diperoleh dapat duraikan sebagai berikut:

1. Selama proses belajar mengajar guru telah melaksanakan semua pembelajaran dengan baik. Meskipun ada beberapa aspek yang belum sempurna, tetapi prosentase pelaksanaannya untuk masing-masing aspek cukup besar.

2. Berdasarkan data hasil pengamatan diketahui bahwa siswa aktif selama proses belajar berlangsung.

3. Kekurangan pada siklus I sebelumnya sudah mengalami perbaikan dan peningkatan sehingga menjadi lebih baik.

4. Hasil belajar siswa pada siklus II telah mencapai ketuntasan belajar yang diharapkan sebesar $80 \%$, meningkat dibandingkan dengan hasil belajar siswa pada Siklus I sebesar $65 \%$.

\section{A. PEMBAHASAN ANTAR SIKLUS}

\section{Hasil Belajar Siswa}

a. Nilai Individu

Tabel 4.3. Rekapitulasi Hasil Tes Formatif Siswa antar Siklus

\begin{tabular}{|c|l|c|c|c|}
\hline No & \multicolumn{1}{|c|}{ Uraian } & $\begin{array}{c}\text { Sebelum } \\
\text { tindakan }\end{array}$ & Siklus I & Siklus II \\
\hline 1. & Nilai terendah tes formatif & 44,0 & 60,0 & 60,0 \\
2. & Nilai tertinggi tes formatif & 68,0 & 92,0 & 95,0 \\
3. & Nilai rata-rata tes formatif & 60,6 & 70,8 & 74,0 \\
4. & Jumlah siswa yang tuntas & 16 & 26 & 36 \\
5. & Prosentase ketuntasan & $40 \%$ & $65 \%$ & $80 \%$ \\
\hline
\end{tabular}


Kategori hasil tes formatif dari hasil tes sebelum tindakan, Siklus I dan Siklus II, dapat dilihat pada tabel berikut :

Tabel 9. Kategori Hasil Tes Sebelum Tindakan, Siklus I, dan Siklus II

\begin{tabular}{|l|l|c|c|c|c|c|c|}
\hline \multirow{2}{*}{ No. } & \multirow{2}{*}{ Kategori } & \multicolumn{2}{|c|}{$\begin{array}{c}\text { Sebelum } \\
\text { Tindakan }\end{array}$} & \multicolumn{2}{c|}{ SIKLUS I } & \multicolumn{2}{c|}{ SIKLUS II } \\
\cline { 3 - 8 } & $\begin{array}{c}\text { Jumlah } \\
\text { Siswa }\end{array}$ & $\%$ & $\begin{array}{c}\text { Jumlah } \\
\text { Siswa }\end{array}$ & $\%$ & $\begin{array}{c}\text { Jumlah } \\
\text { Siswa }\end{array}$ & $\%$ \\
\hline 1. & Sangat baik & 0 & 0 & 3 & 7,5 & 6 & 15,0 \\
2. & Baik & 0 & 0 & 8 & 20,0 & 10 & 25,0 \\
3. & Cukup Baik & 16 & 40 & 15 & 37,5 & 16 & 40,0 \\
4. & Kurang baik & 24 & 60 & 14 & 35,0 & 8 & 20,0 \\
\hline \multicolumn{2}{|l}{ Jumlah } & 40 & 100 & 40 & 100 & 40 & 100 \\
$\%$
\end{tabular}

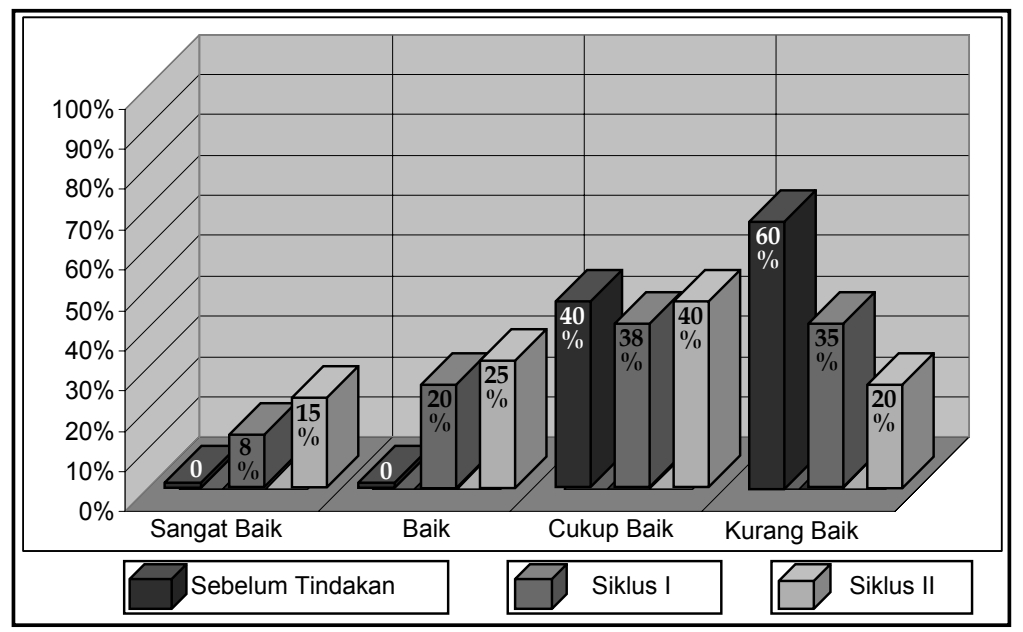

Gambar 2. Histogram hasil tes Sebelum Tindakan, Siklus I dan Siklus II

Secara garis besar hasil belajar individu setelah dilakukan tindakan terjadi peningkatan secara klasikal baik pada Siklus I maupun pada Siklus II. Dengan demikian dari sudut ketuntasan

108 Jurnal PHENOMENON, Volume 2 Nomor 1, November 2011 
Upaya Meningkatkan Aktivitas Belajar .....

belajar (yang mendapat nilai di atas KKM atau lebih dari 65,0) telah mengalami peningkatan yaitu sebelum tindakan dari 16 siswa (40\%) menjadi 26 siswa (65\%) pada Siklus I dan naik menjadi 32 siswa $(80 \%)$ pada Siklus II.

\section{b. Nilai Kelompok}

Tabel 10. Penghargaan Kelompok Pada Siklus I dan Siklus II

\begin{tabular}{|c|c|c|c|c|c|}
\hline \multirow[b]{2}{*}{ No. } & \multirow[b]{2}{*}{ Kategori } & \multicolumn{2}{|c|}{ Siklus I } & \multicolumn{2}{|c|}{ Siklus II } \\
\hline & & $\begin{array}{c}\text { Jumlah Ke- } \\
\text { lompok }\end{array}$ & $\%$ & $\begin{array}{l}\text { Jumlah } \\
\text { Kelompok }\end{array}$ & $\%$ \\
\hline 1 & Terbaik & 1 & 10 & 4 & 40 \\
\hline 2 & Baik & 5 & 50 & 5 & 50 \\
\hline 3 & Cukup Baik & 3 & 30 & 1 & 10 \\
\hline 4 & Kurang baik & 1 & 10 & 0 & 0 \\
\hline & Jumlah & 10 & $\begin{array}{c}100 \\
\%\end{array}$ & 10 & $\begin{array}{c}100 \\
\%\end{array}$ \\
\hline
\end{tabular}

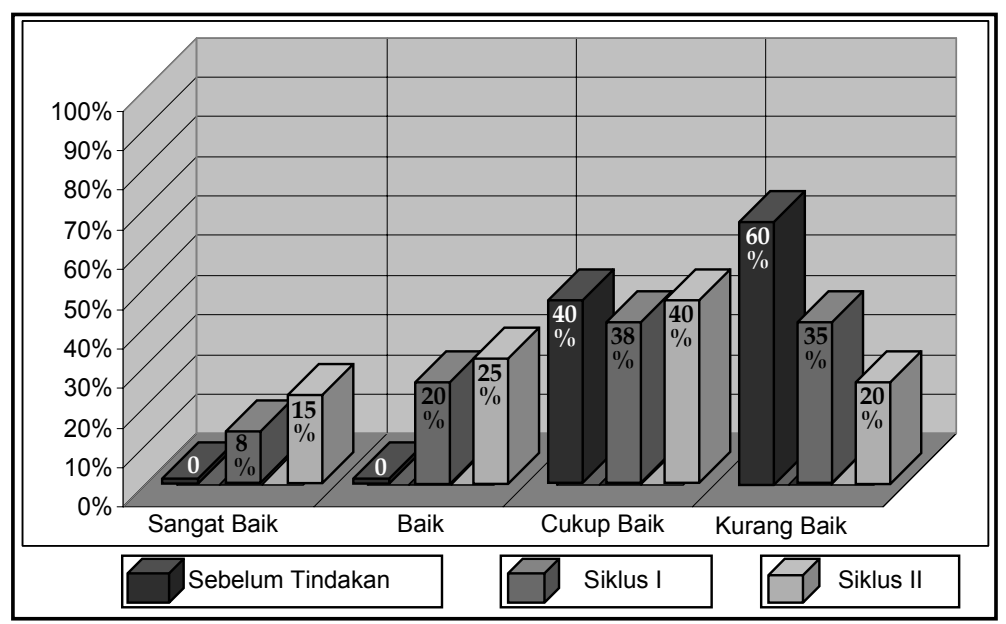

Gambar 3. Histogram penghargaan kelompok pada Siklus I dan Siklus II 
Dari tabel di atas menunjukkan bahwa kelompok dengan kategori terbaik pada Siklus I sebanyak $10 \%$ pada Siklus II mengalami peningkatan menjadi $40 \%$, kategori baik pada Siklus I sebanyak $50 \%$ pada Siklus II tetap $50 \%$, kategori cukup baik pada Siklus I sebanyak $30 \%$ pada Siklus II berkurang menjadi $10 \%$, dan pada Siklus I untuk kategori kurang baik sebanyak 10 $\%$ pada Siklus II tidak ada (0\%).

\section{Aktivitas Siswa}

Aktivitas guru maupun aktivitas siswa telah menunjukkan peningkatan yang positif, dalam arti bahwa guru telah melaksanakan pembelajaran sesuai dengan apa yang diharapkan dalam rencana pembelajaran. Dimana kekurangan-kekurangan pada siklus I sudah diantisipasi pada Siklus II.

Sedangkan aktivitas siswa dalam kelompok telah mengalami peningkatan dalam arti bahwa sebagian besar siswa sudah aktif dalam proses pembelajaran. Hal ini ditandai dengan mengerjakan kegiatan sekaligus menyelelesaikan soal yang ditugaskan kepada kelompoknya, apabila terdapat hal-hal yang kurang dimengerti, tanpa ragu-ragu siswa segera bertanya baik kepada anggota kelompoknya maupun kepada guru sehingga mereka mampu mengemukakan pendapatnya dan menjawab pertanyaan baik kepada guru atau anggota kelompoknya.

Selain itu pula siswa sudah menyadari dan memahami sasaran yang harus dicapai dalam pembelajaran dengan menggunakan media pembelajaran berbasis ICT yang dipadukan dengan interaksi diskusi kelompok sehingga sebagian besar siswa aktif dalam proses belajar-mengajar.

\section{PEMBAHASAN HASIL PENELITIAN}

\section{Ketuntasan Hasil Belajar Siswa}

Setelah pelaksanaan tindakan melalui pendekatan pembelajaran interpretatif yang berbasis media ICT dan interaksi diskusi kelompok pada pokok bahasan kinematika gerak lurus diperoleh gambaran ketuntasan belajar siswa melalui tes formatif I pada tindakan Siklus I, dimana dari 40 siswa nilai rata-rata 
hasil belajar siswa 70,8 dengan jumlah siswa yang memperoleh nilai di atas KKM sejumlah 26 siswa atau $65 \%$. Secara klasikal ketuntasan hasil belajar siswa pada Siklus I meningkat sehingga dikategorikan cukup baik.

Pada tindakan Siklus II dari 40 siswa, secara deskriptif nilai rata-rata hasil belajar siswa melalui tes formatif II pada tindakan Siklus II sebesar 74,0 dengan ketuntasan belajar siswa sebesar 80 $\%$ sehingga dikategorikan sangat baik.

Dengan demikian berdasarkan hasil analisis ketuntasan hasil belajar siswa secara klasikal mengalami peningkatan yaitu dari sebelum tindakan sebesar 16 siswa (40\%), pada Siklus I menjadi 26 siswa (65\%), dan pada Siklus II meningkat menjadi 32 siswa atau $80 \%$.

\section{Kemampuan Guru dalam Mengelola Pembelajaran}

Berdasarkan analisis data, dalam proses pembelajaran pada materi pokok kinematika gerak lurus dengan menerapkan pembelajaran interpretatif berbasis ICT dan interaksi diskusi kelompok dalam setiap siklus aktivitas pembelajaran mengalami peningkatan. Hal ini berdampak positif terhadap proses pembelajaran mengingat kembali materi pelajaran yang telah diterima selama ini, yaitu dapat ditunjukkan nilai rata-rata hasil belajar siswa pada setiap siklus yang mengalami peningkatan.

\section{Aktivitas Guru dan Siswa dalam Pembelajaran}

Berdasarkan analisis data, diperoleh aktivitas siswa dalam proses pembelajaran interpretatif berbasis ICT dan interaksi diskusi kelompok yang paling dominan adalah bekerja dengan menggunakan alat/media, mendengarkan, memperhatikan penjelasan guru, dan diskusi antar siswa serta antara siswa dengan guru. Jadi dapat dikatakan bahwa aktivitas siswa dapat dikategorikan aktif.

Sedangkan untuk aktivitas guru selama pembelajaran telah melaksanakan langkah-langkah belajar aktif dengan baik. Hal ini terlihat dari aktivitas guru yang muncul di antaranya aktivitas membimbing dan mengamati siswa dalam mengerjakan ke- 
giatan, menjelaskan, memberi umpan balik (feedback), evaluasi, tanya jawab dimana prosentase untuk aktivitas di atas cukup besar.

Berdasarkan hasil analisis aktivitas siswa dalam kelompoknya serta hasil belajar siswa dalam pemberian tindakan dengan menggunakan pembelajaran interpretatif berbasis ICT dan interaksi diskusi kelompok diperoleh peningkatan baik aktivitas siswa dalam kelompok maupun hasil belajar siswa, sehingga dapat disimpulkan bahwa hipotesa penelitian yang telah dirumuskan sebelumnya dapat diterima.

\section{PENUTUP}

\section{A. SIMPULAN}

1. Pembelajaran interpretatif yang berbasis ICT dan interaksi diskusi kelompok memiliki dampak positif dalam meningkatkan hasil belajar siswa yang ditandai dengan peningkatan ketuntasan belajar siswa yaitu dari sebelum tindakan sebesar 16 siswa (40\%) yang tuntas belajar (yang memperoleh nilai di atas $\mathrm{KKM}=65,0)$, pada Siklus I menjadi 26 siswa $(65 \%)$, dan pada Siklus II meningkat menjadi 32 siswa atau $80 \%$.

2. Penerapan Pembelajaran interpretatif yang berbasis ICT dan interaksi diskusi kelompok mempunyai pengaruh positif, disamping meningkatkan aktivitas belajar siswa juga mampu meningkatkan motivasi belajar siswa yang ditunjukan dengan observasi penggunaan media ICT bahwa media mampu meningkatkan minat/motivasi siswa terhadap materi yang disajikan sehingga siswa menjadi termotivasi untuk belajar.

\section{B. IMPLIKASI DAN REKOMENDASI}

Berdasarkan hasil penelitian yang diperoleh dalam Penelitian Tindakan Kelas (PTK) ini dapat direkomendasikan bahwa dengan penerapkan pendekatan Pembelajaran interpretatif yang berbasis 
ICT dan interaksi diskusi kelompok pada siswa dapat meningkatkan aktivitas dan hasil belajar, khususnya pada standar kompetensi menerapkan konsep dan prinsip kinematika gerak lurus mata pelajaran Fisika kelas X di MAN Kendal. Pengembangan lebih lanjut pendekatan ini sesuai untuk diterapkan pada standar kompetensi lainnya dan perlu dilakukan penelitian lebih lanjut.

\section{SARAN}

1. Guru hendaknya melaksanakan pembelajaran dengan Pendekatan, metode dan media pembelajaran yang berbasis ICT sangat tepat untuk membangkitkan aktivitas belajar siswa.

2. Bagi siswa, peningkatan belajar melalui interaksi dalam diskusi kelompok lebih baik dari pada belajar sendiri.

5. Bagi kepala sekolah hendaknya selalu memberi motivasi kepada para guru untuk melakukan inovasi pembelajaran.

4. Perlu adanya penelitian lebih lanjut, 


\section{DAFTAR PUSTAKA}

Agam Supriyanta, (2007). Peningkatan Hasil Belajar Fisika Siswa Kelas XI SMA N 2 Cianjur Melalui Metode Pembelajaran Interpretatif menggunakan Internet, Jakarta: Depdiknas.

Arikunto, Suharsimi, (2006). Manajemen Penelitian, Jakarta: Bumi Akasara.

Asnawir, Basyiruddin Usman, (2006). Media Pembelajaran, Jakarta: Ciputat Press.

Asrori, Mohammad, Prof. Dr., (2008). Penelitian Tindakan Kelas, Bandung: CV Wacana Prima.

Depag, (2002) .Pedoman Pembelajaran Mata Pelajaran Fisika, Jakarta: Departemen Agama RI - Development of Madrasah Aliyahs Project (DMAP).

Depdiknas, 2006. Kurikulum Tingkat Satuan Pendidikan, Jakarta: Ditjen Dikasmen Dikmenum Departemen Pendidikan Nasional.

Hamalik, Oemar, (2006). Proses Belajar Mengajar, Jakarta: Bumi Aksara.

Kanginan, Marthen, (2007). Fisika untuk SMA Kelas X Semester 1 (KTSP 2006), Jakarta: Erlangga.

Purwanto, Ngalim M, (2007). Psikologi Pendidikan, Bandung : PT. Remaja Rosdakarya.

Rudi Susilana, Cece Riyana, (2008). Media Pembelajaran, Hakikat, Pengembangan, dan Penilaian, Bandung: CV. Wacana Prima.

Sardiman, (2007). Interaksi dan Motivasi Belajar Mengajar, 
Jakarta: Raja Grafindo Perkasa.

Slameto, (2007). Belajar dan Faktor-faktor yang Mempengaruhi, Jakarta: Rineka Cipta.

Sukidin, dkk, (2002). Manajemen Penelitian Tindakan Kelas, Jakarta: Insan Cendekia.

Sumiati, Asra, (2008). Metode Pembelajaran, Bandung: CV.Wacana Prima.

Supriyono, Koes, (2003). Strategi Pembelajaran Fisika, Malang: Universitas Negeri Malang (UNM Malang).

Suparman, (2007). Meningkatkan Aktivitas \& Hasil Belajar Di Materi Listrik Statis Dengan Pembelajaran Berbasis ICT Pada Kelas XII di SMA Negeri 4 Kendari, Jakarta: Depdiknas.

Usman, Moh Uzer, (2006). Menjadi Guru Profesional, Bandung: PT. Remaja Rosdakarya Bandung.

Wartini, dkk., (2010). Modul Fisika untuk SMA/MA 10B Semester Genap, Sukoharjo: CV Seti-Aji.

Winkel, WS., (2007). Psikologi Pendidikan dan Evaluasi Belajar, Jakarta: Gramedia. 